\title{
Online Learning And Its Challenges For Parents
}

\author{
Ester Lina Situmorang, ${ }^{1 *}$ Benteng Martua Mahuraja Purba ${ }^{2}$ \\ Christian Education Study Program, Real Theological Seminary Batam \\ Linae440@gmail.com
}

\begin{abstract}
Technology has significantly brought changes in all aspects of human life, the changes that occur require everyone to change from old habits to new habits that are not used to be done. Changes in general in face-to-face classes began to shift to virtual classes. Even the elements of education have undergone many changes both parents, students and teachers. They experience new teaching patterns and ways of teaching. Learning places are transformed and can be done at home, public places, and so on. Time and place are no longer a barrier to teaching and learning activities because they can be done online. Online learning is carried out by utilizing existing technology through media that uses the internet to carry out teaching and learning processes such as cellphones and laptops. This media will support the teaching and learning process through available applications such as whatsApp, google classroom and so on. Learning brings many challenges and obstacles faced by parents in particular. Of course this is a challenge in itself for parents in monitoring children's learning activities, especially in the application of technology as a learning medium for children.

Keywords: Challenges, Online Learning, Parents
\end{abstract}

\section{INTRODUCTION}

Educating children in the learning process in the Post-modern era is not only the task of the teacher, but at this time parents are required to guide and monitor children's learning at home. It is not appropriate if the responsibility is only delegated to the teacher in the teaching and learning process. The changing times provide convenience and challenges in Christian education, education is of course not only about the responsibility of formal educational institutions, ${ }^{1}$ but also informally including parental support.

Parents are required to play an active role in guiding their children to study at home. The lessons they have to follow every day, parents at home must know, the child's homework assignments have to be completed. Children's learning media must also be provided, parents must provide time to guide their children to study at home every day. Teachers and parents have an equally important role in education. Parents need to be open to changes in order to be able to anticipate the challenges of accelerating in the world of education which are mostly done online. So that children can continuously develop themselves in a relevant way both formally and informally.

${ }^{1}$ Manahan Simanjuntak, "Buku Prosiding Seminar Nasional STT REAL BATAM," in Keluarga Yang Misioner, ed. .M.Pd Dr.Otieli Harefa,M.Th (Batam: STT REAL BATAM, 2018), 61-79. 


\section{METHOD}

This paper is prepared using descriptive qualitative research methods. The data obtained through the books are analyzed in depth and described, and arranged in such a way that readers can easily understand them.

\section{RESULTS AND DISCUSSION \\ Online Learning And Its Challenges For Parents}

The development of communication and information technology has opened up wide possibilities for use in the field of education. This is due to the rapid development of communication and information technology, for example online learning is a public discourse in Indonesia that is often discussed in the world of education today, and has become the center of attention of all people, not only educational institutions, but also all parents, society and the state. Learning is a learning system that utilizes electronic media as a tool to assist learning activities directed at the use of computer technology and the internet. Through computers students can learn individually either programmed or unprogrammed. ${ }^{2}$ Students can access various learning materials and information on the internet without being programmed. The internet can also be used programmatically, one of which is online learning, which is a form of distance learning that utilizes technology and information.

\section{Learning Limitations and Media Resources}

Distance learning with networks certainly requires media and resources that support learning. The media used for learning is not the same as the classroom situation in conventional teaching patterns (face to face), but the learning process without the presence of the teacher is replaced by learning media. ${ }^{3}$ Media and learning resources can use gadgets or laptops by using zoom, google meet, facebook messenger, whatsapp video call, etc.

For parents who are not accustomed to using technology, of course it will be an obstacle and a challenge for them to teach their children to learn at home, the availability of media and learning resources is very limited, besides they are not expert in using the internet. Parents who have more than one child, with learning from home, will certainly feel unable to teach their children to study especially those who do not have facilities for learning such as gadgets, internet, or maybe those with low income sources. Even those who have gadgets feel inadequate because there are so many children's tasks that will be done through learning

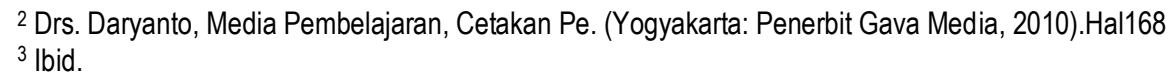


media. This is a challenge for parents, and as a result their children will be left behind because they are not able to follow the online learning system, inevitably parents have to try to provide media and learning resources for their children and must try to learn to upgrade themselves to be able to understand internet usage and master technology. Times have changed and parents must change too. Because parents will replace teachers at home to teach their children to learn, teachers are only facilitators and are limited to controlling children to learn in their respective homes. During online learning, parents are fully responsible for teaching their children to learn at home through learning materials that have been distributed through learning media.

\section{Limited time}

There are many limitations faced during learning, one of which is time constraints, the teacher may only take two hours a day to accompany students to study, parents must provide time for their children to accompany them to study at home. No matter how busy parents are, they must provide time for their children because the learning system using gadgets (smart phones) needs to be accompanied by parents to learn at home, because underage children must be supervised, controlled, in using gadgets. If parents do not provide time for their children to accompany children to study at home, it will cause unwanted things, such as children may not study seriously, play online games, open sites that are not support for learning. But the wise use of smart phones or gadgets will have a positive impact on the child's development. ${ }^{4}$ This challenge makes parents really have to give the time to ensure their children follow the learning, because the online learning system is not optimal and the results that are achieved are not the same as studying in school face-to-face. Online learning is very limited in understanding and delivery, therefore parents have a role in helping their children to follow any lessons that have been scheduled every day and ensure their children are able to do the assignments given by the teacher, so they can follow the learning activities well and get the best score.

\section{Mastery of Technology}

The internet world is now very fast, everything is completely online, regardless of age, regardless of position, as if we all have to be forced to master technology and know the virtual world. ${ }^{5}$ Why do people often talk about this virtual world? Regardless of our age and position, it is as if we must be forced to

\footnotetext{
${ }^{4}$ Simanjuntak, "Buku Prosiding Seminar Nasional STT REAL BATAM."

${ }^{5}$ M.A. Pof.Dr.Azhar Arsyad, Media Pembelajaran, Revisi-Ce. (Jakarta, 2015).
} 
know the world of the internet. The definition of the internet is a computer network that is interconnected and can communicate with each other globally/internationally either via cable, radio, satellite, cellphone and others. The implementation of the internet has been widely applied throughout the world, especially in the post-modern era, there is online learning where students/students and teachers/lecturers do learning activities not face-to-face (physically separate but can interact and collaborate indirectly, but through online. This system is the use of technological sophistication. Learning can be done through video conferencing, downloading learning materials. This can be done with applications that are available to simplify the online learning process such as google meet, google classroom, etc. Of course parents do not always understand technological developments at this time. But inevitably they have to learn, how can lead their children to learn at home through learning media with networks Parents who do not have knowledge about technology are forced to learn, otherwise it will affect their children can't wheeze follow online lessons. At this time, there may be many parents who give up teaching their children to learn at home because of the inability to master technology and the unavailability of learning resources and media. Teaching materials that have been prepared by the teacher to assist the learning process, which are materials that students must do in writing, audio, and video. Parents should be able to download the material and direct their children to work on it. For this reason, parents must master technology and be able to guide children to study at home.

\section{CONSLUSION}

Distance learning using networks or online learning has many challenges faced by parents. Parents at home replace the role of teachers in school, teachers only guide children to learn through materials or teaching materials that have been prepared through learning media for students. Parents are the ones who play an active role at home to teach their children to learn at home. Challenges faced by parents in online learning such as limitations and media resources, limited time, mastery of technology

Demand that parents must change and follow changes, especially in this post-modern era. Parents can no longer fully assign responsibility to the teacher in learning activities, but parents must be able to guide, help and direct their children to be able to take part in online learning, so that their children do not fall behind in learning and are able to complete all homework. which has been given by the teacher. 


\section{BIBLIOGRAPHY}

Drs. Daryanto. Media Pembelajaran. Cetakan Pe. Yogyakarta: Penerbit Gava Media, 2010.

Pof.Dr.Azhar Arsyad, M.A. Media Pembelajaran. Revisi-Ce. Jakarta, 2015.

Simanjuntak, Manahan. "Buku Prosiding Seminar Nasional STT REAL BATAM." In Keluarga Yang Misioner, edited by .M.Pd Dr.Otieli Harefa,M.Th, 61-79. Batam: STT REAL BATAM, 2018.

Uji, Manahan. "Real Didache Jurnal STT REAL Batam." Real Didache 3 (2018): 87-120. 